Journal of Clinical Investigation

Journal of Clinical In
Vol. 42, No. 4, 1963

\title{
SICKLING PHENOMENON PRODUCED BY HYPERTONIC SOLUTIONS: A POSSIBLE EXPLANATION FOR THE HYPOSTHENURIA OF SICKLEMIA *
}

\author{
By PASQUALE E. PERILLIE † AND FRANKLIN H. EPSTEIN
}

(From the Department of Internal Medicine, Yale University School of Medicine, New Haven, and the Medical Service, Veterans Administration Hospital, West Haven, Conn.)

(Submitted for publication November 2, 1962; accepted December 27, 1962)

Hyposthenuria and recurrent episodes of hematuria are well-known complications of the sicklecell disorders (1). Although it has been suggested that the defect in renal concentrating ability results from the presence of sickle hemoglobin within the circulating erythrocytes, there has been no satisfactory explanation for the special vulnerability of the kidney to the presence of such cells.

A physiological characteristic differentiating the kidney from all other organs of the body is the high concentration of solutes normally attained in blood traversing the capillaries of the renal medulla $(2,3)$. It seemed worthwhile, therefore, to examine the effects of hypertonic solutions upon erythrocytes from patients with sickle-cell disease. The sickling phenomenon was found to be enhanced by concentrated solutions of sodium salts, and these results have suggested an explanation for the hyposthenuria associated with sickle-cell anemia.

\section{METHODS}

Paticnts. Ten hematologically normal white and $\mathrm{Ne}-$ gro subjects and a group of ten patients with hemoglobinopathies other than sickle-cell disease served as controls in the present investigation. The disorders represented in the latter group were hemoglobin $\mathrm{C}$ disease, hemoglobin $\mathrm{C}$ trait, thalassemia major, and thalassemia minor. The main study group consisted of 16 patients with sickle-cell disease as listed in Table I.

Sickling phenomenon. A drop of capillary blood was mixed with 2 drops of solutions of $\mathrm{NaCl}$ having osmolalities ranging from 300 to $2,000 \mathrm{mOsm}$ per $\mathrm{kg}$. The mixtures were immediately examined microscopically for the presence of sickling. Standard metabisulfite sickle preparations were also performed in the usual manner (4).

The percentage of sickled cells present in varying con-

* Aided by U. S. Public Health Service grant H-834, FR 3803, and H-1577, and by grants from the New Britain and New Haven Heart Associations, and the Lawrence Gelb Foundation.

$\dagger$ Clinical Investigator, Veterans Administration Hospital, West Haven, Conn. centrations of saline was determined by diluting blood 100 times in an ordinary Thoma erythrocyte-counting pipette, using as diluting fluid solutions of $\mathrm{NaCl}$ with osmolalities ranging from 300 to $2,000 \mathrm{mOsm}$ per $\mathrm{kg}$. After mixing, a drop of the red cell suspension was placed in a hemocytometer and 500 cells were counted under high power.

All tests were done at room conditions for temperature and oxygen. The mixtures of red cells and saline were shaken vigorously for several minutes to promote equilibration with room air. In a few cases, the $\mathrm{pO}_{2}$ of the red cell-saline mixtures showing the sickling phenomenon was determined in a Beckman physiological gas analyzer. The $\mathrm{pH}$ of the mixtures was determined in a Cambridge $\mathrm{pH}$ meter.

Viscosity. a) Red cell suspensions. Oxalated venous blood samples were centrifuged, and the plasma was discarded. Saline solutions of varying sodium concentration were added to the separate red cells so that the final hematocrit of each suspension was $35 \%$. The viscosity of these suspensions was then determined with an Ostwald viscometer in a constant-temperature water bath at $37^{\circ} \mathrm{C}$. The results were expressed as viscosity relative to distilled water as unity.

b) Hemoglobin solutions. Separated red cells were treated by two methods to obtain hemoglobin solutions for study. Red cells were lysed with distilled water and toluene, and the stroma were separated by centrifuging and filtering through gauze. Desiccated $\mathrm{NaCl}$ was then added to obtain final concentrations of solute ranging from 300 to $1,200 \mathrm{mOsm}$ per $\mathrm{kg}$ as determined with a Fiske osmometer. The final hemoglobin concentrations varied between 16 and $20 \mathrm{~g}$ per $100 \mathrm{ml}$. The viscosity of these solutions was determined with an Ostwald viscometer.

In another study, separated red cells from two patients with sickle-cell anemia and three normal subjects were washed three times with isotonic or hypertonic saline $(1,200 \mathrm{mOsm}$ per $\mathrm{kg})$. Hemolysates were then obtained by freezing and thawing, followed by rapid centrifugation and filtering through gauze. The viscosity of these solutions was determined with an Ostwald viscometer.

Effect of hypertonic solutions on packed cell volume. Blood from five subjects was mixed with an equal volume of saline, the concentration of which varied from 300 to $2,000 \mathrm{mOsm}$ per $\mathrm{kg}$. The hematocrit of the resulting mixture was determined by the method of Wintrobe (5).

Studies of renal function. In studies of renal concentrating ability, urine was collected without the use of a 
TABLE I

Laboratory data on patients with sickle-cell disease

\begin{tabular}{|c|c|c|c|c|c|c|c|c|c|}
\hline \multirow[b]{3}{*}{ Patient } & \multirow[b]{3}{*}{ Age } & \multirow[b]{3}{*}{ Diagnosis } & \multirow{2}{*}{\multicolumn{4}{|c|}{ Hemoglobin pattern* }} & \multicolumn{2}{|c|}{ Sickle preparation } & \multirow[b]{3}{*}{ Cosm. $\neq$} \\
\hline & & & & & & & \multirow{2}{*}{$\begin{array}{l}\text { Metabi- } \\
\text { sulfite }\end{array}$} & \multirow{2}{*}{$\begin{array}{l}\text { Hyper- } \\
\text { tonic } \\
\text { saline }\end{array}$} & \\
\hline & & & $\mathrm{A}$ & $\mathrm{S}$ & $\mathrm{C}$ & $\mathrm{F} \dagger$ & & & \\
\hline & years & & $\%$ & $\%$ & $\%$ & $\%$ & & & $\mathrm{mOsm} / \mathrm{kg}$ \\
\hline 1 & 41 & Sickle-cell anemia & & 91.0 & & 9.0 & + & + & 350 \\
\hline 2 & 21 & Sickle-cell anemia & & 98.0 & & 2.0 & + & + & \\
\hline 3 & 22 & Sickle-cell anemia & & 96.0 & & 4.0 & + & + & 407 \\
\hline 4 & 29 & Sickle-cell anemia & & 97.4 & & 2.6 & + & + & 420 \\
\hline 5 & 28 & Sickle-cell anemia & & 98.4 & & 1.6 & + & + & 435 \\
\hline 6 & 9 & Sickle-cell anemia & & 94.0 & & 6.0 & + & + & 472 \\
\hline 7 & 42 & Sickle-cell thalassemia & & 86.0 & & 14.0 & + & + & 406 \\
\hline 8 & 14 & Sickle-cell thalassemia & 15.0 & 70.0 & & 15.0 & + & + & 628 \\
\hline 9 & 31 & Sickle-cell hemoglobin C & & 56.0 & 42.0 & 2.0 & + & + & $\begin{array}{l}0<0 \\
529\end{array}$ \\
\hline 10 & 26 & Sickle-cell hemoglobin C & & 55.0 & 44.0 & 1.0 & & & \\
\hline 11 & 21 & Sickle-cell trait & 59.0 & 40.0 & & 1.0 & + & + & \\
\hline 12 & 26 & Sickle-cell trait & 57.0 & 42.0 & & 1.0 & + & + & \\
\hline 13 & 32 & Sickle-cell trait & 53.0 & 45.0 & & 2.0 & + & + & 557 \\
\hline 14 & 63 & Siclke-cell trait & 63.0 & 35.5 & & 1.5 & + & - & 380 \\
\hline 15 & 35 & Sickle-cell trait & 57.0 & 41.0 & & 2.0 & + & - & \\
\hline 16 & 41 & Sickle-cell trait & 51.2 & 47.2 & & 1.6 & + & - & 542 \\
\hline
\end{tabular}

* By filter paper electrophoresis.

$\dagger$ Alkali denaturation.

$\ddagger$ Maximal urinary osmolality, after an injection of vasopressin in oil.

catheter by asking patients to stand and void. The reabsorption of solute-free water $\left(T^{{ }^{2}} \mathrm{H}_{2} \mathrm{O}\right)$ was determined during an osmotic diuresis induced by the infusion of $5 \%$ mannitol or $15 \%$ glucose in $0.9 \%$ saline. Urine was collected every 15 minutes, serum every half hour. Vasopressin was given intravenously at the rate of $200 \mathrm{mU}$ per hour. Inulin was measured by the method of Walser, Davidson, and Orloff (6). Osmolality of serum, urine, and red cell diluting solutions was determined with a Fiske osmometer. For the measurement of maximal urinary osmolality $\left(U_{\max }\right), 5 \mathrm{U}$ of vasopressin in oil ${ }^{1}$ was injected intramuscularly, the patient was asked to void four times at half-hour intervals, and the highest urinary osmolality was taken as $\mathrm{U}_{\max }$.

\section{RESULTS}

Sickling phenomenon induced by hypertonic $\mathrm{NaCl}$ solution (Table I, Figures 1-3). Sickling occurred within a few seconds in all patients with sickle-cell anemia and sickle-cell variants when their blood was mixed with hypertonic saline ( $\mathrm{Ta}$ ble I, Figure 1). Instantaneous sickling also was observed in three of the six patients with sicklecell trait. No sickling was seen in any of the nonsicklemic subjects studied, although crenation of erythrocytes was apparent in the concentrated salt solutions. The final $\mathrm{pH}$ of the red cell mixtures

1 Pitressin Tannate in Oil, courtesy of Parke, Davis \& Company, Detroit, Mich. was between 7.3 and 7.4, and the $\mathrm{pO}_{2}$ of five hypertonic mixtures tested, in which sickling was present, ranged between 95 and $140 \mathrm{~mm} \mathrm{Hg}$, corresponding to a probable oxygen saturation of more than $85 \%(7,8)$. [The oxygen saturation of a mixture of the blood of Patient 1 (Table I) with an equal volume of hypertonic saline $(1,600$ mOsm per $\mathrm{kg}$ ), in which sickling was pronounced, was $90 \%$, as determined directly with a reflectance oximeter.] In order to determine the reversibility of the sickling effects of hypertonic solutions, samples of the saline mixtures containing sickled cells were diluted with distilled water or isotonic saline. The sickling phenomenon was quickly reversed when the final concentration approached $500 \mathrm{mOsm}$ per $\mathrm{kg}$.

An increase in sickling in the blood of patients with sickle-cell anemia (S-S disease) was first observed at an osmolality of $600 \mathrm{mOsm}$ per $\mathrm{kg}$. As the concentration of the salt solution bathing the red cells increased, the percentage of sickled cells reached a maximum at 600 to $1,000 \mathrm{mOsm}$ per $\mathrm{kg}$ and usually did not rise with further increase in extracellular tonicity (Figure 2). In patients with sickle-cell trait, the same phenomenon was observed, but sickled cells were less numerous than in subjects with sickle-cell anemia (Figure 3 ).

Effect of hypertonic solutions of mannitol, su- 


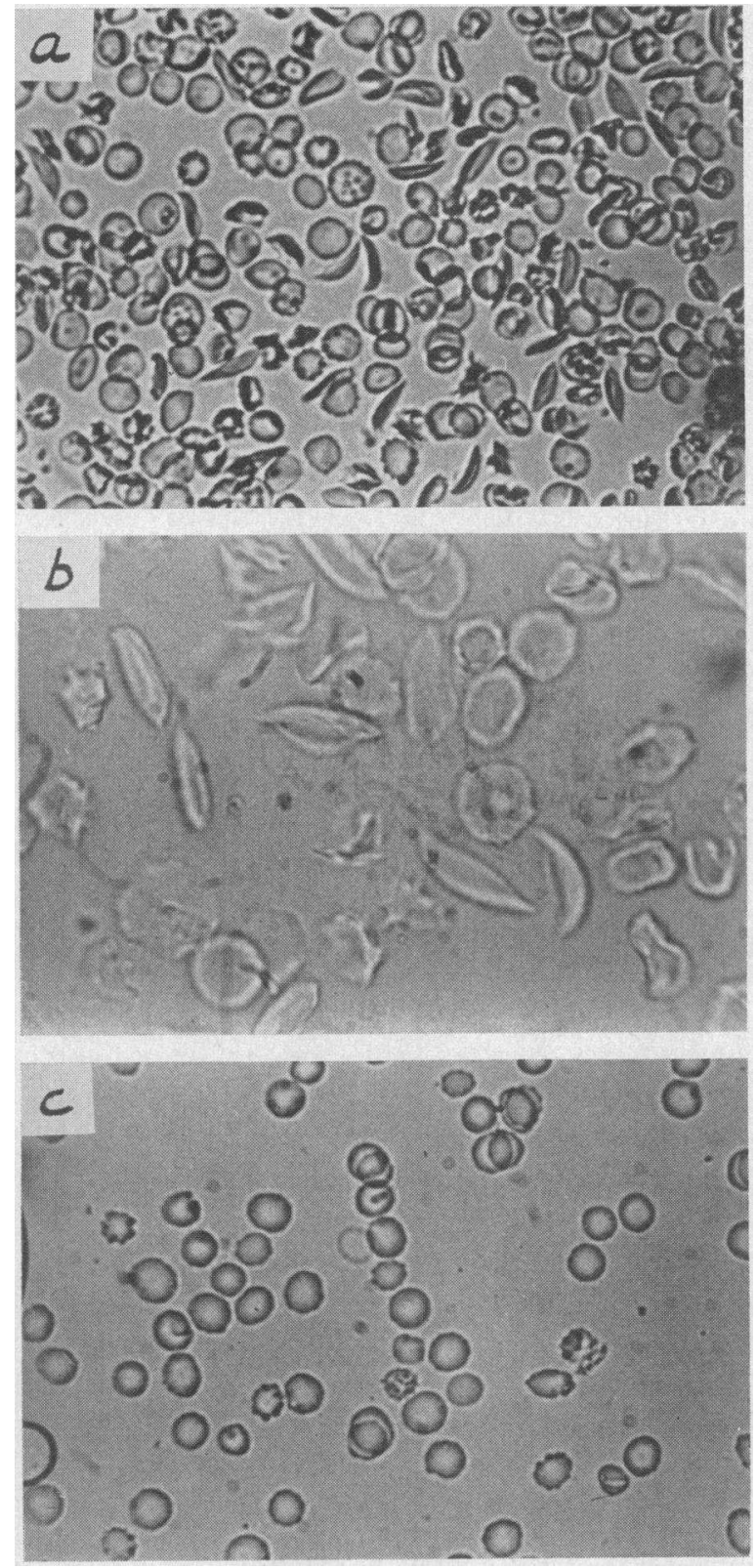

Fig. 1 a. Red cells from Patient 1 (with sickleCell anemia; Table I) SUSPENded IN hypertonic SALINE $(1,200$ MOSM PER KG) $\times 430$. b. SAME, OIL IMMERSION, $\times 970$. C. RED CELlS FRom SAME PATIENT SUSPENDED IN ISOTONIC SALINE, $\times 430$.

crose, and urea. The sickling phenomenon was also elicited in patients with sickle-cell anemia by hypertonic solutions of mannitol and sucrose (1,000 to $1,200 \mathrm{mOsm}$ per $\mathrm{kg}$ ). Exact enumeration of the percentage of cells sickled was difficult because of clumping of red cells in these sugary solutions. By contrast, a hypertonic solution of urea containing 900 mmoles per $\mathrm{L}$ of urea dissolved in $0.9 \% \mathrm{NaCl}$ did not produce sickling.

Viscosity measurements (Figures 4 and 5). Suspensions of red cells from four patients with sickle-cell anemia showed a progressive increase in viscosity from an osmolality of 300 to about 1,200 mOsm per $\mathrm{kg}$ (Figure 4). Red cells from patients with sickle trait and from nonsicklemic subjects showed no change in viscosity under the same conditions (Figure 5).

In contrast to the behavior of suspensions of intact red cells, the viscosity of solutions of hemoglobin prepared from sicklemic patients was not changed by the addition of salt (Figure 4). However, when hemoglobin was concentrated within the red cell by washing cells from patients with sickle-cell anemia in hypertonic solutions of saline, subsequent freezing and thawing produced a gelatinous mass from which stroma could not be separated by centrifugation for one hour at $2,000 \mathrm{rpm}$. Fluidity was not restored by the addition of isotonic saline. Normal red cells subjected to the same procedure produced clear solutions of hemoglobin which flowed easily.

Effect of hypertonic solutions upon red cell volume (Table II). When normal blood and blood from patients with sickle-cell disease was diluted with equal volumes of increasingly concentrated salt solutions, the hematocrit of the resulting mixture diminished to a minimum when the diluting solution contained from 500 to $1,200 \mathrm{mOsm}$ per $\mathrm{kg}$. With subsequent increases in the tonicity of the diluting fluid, there was no appreciable further decline in packed cell volume.

Studies of renal concentrating capacity (Tables I and III, Figures 6 and 7). As noted by others (9-12), maximal urinary concentration at low urine flows was greatly diminished in patients with sickle-cell anemia, but less severely or consistently so in subjects with sickle-cell variants or sickle-cell trait (Table I). During osmotic loading, on the other hand, in confirmation of previous reports (12-14), urinary concentration in patients with sickle-cell anemia remained remarkably constant (Figure 6), resulting in a progressive rise in $\mathrm{T}^{\mathrm{c}} \mathrm{H}_{2} \mathrm{O}$ with increasing solute diuresis (Figure 7).

Urinary concentration at both low and high 


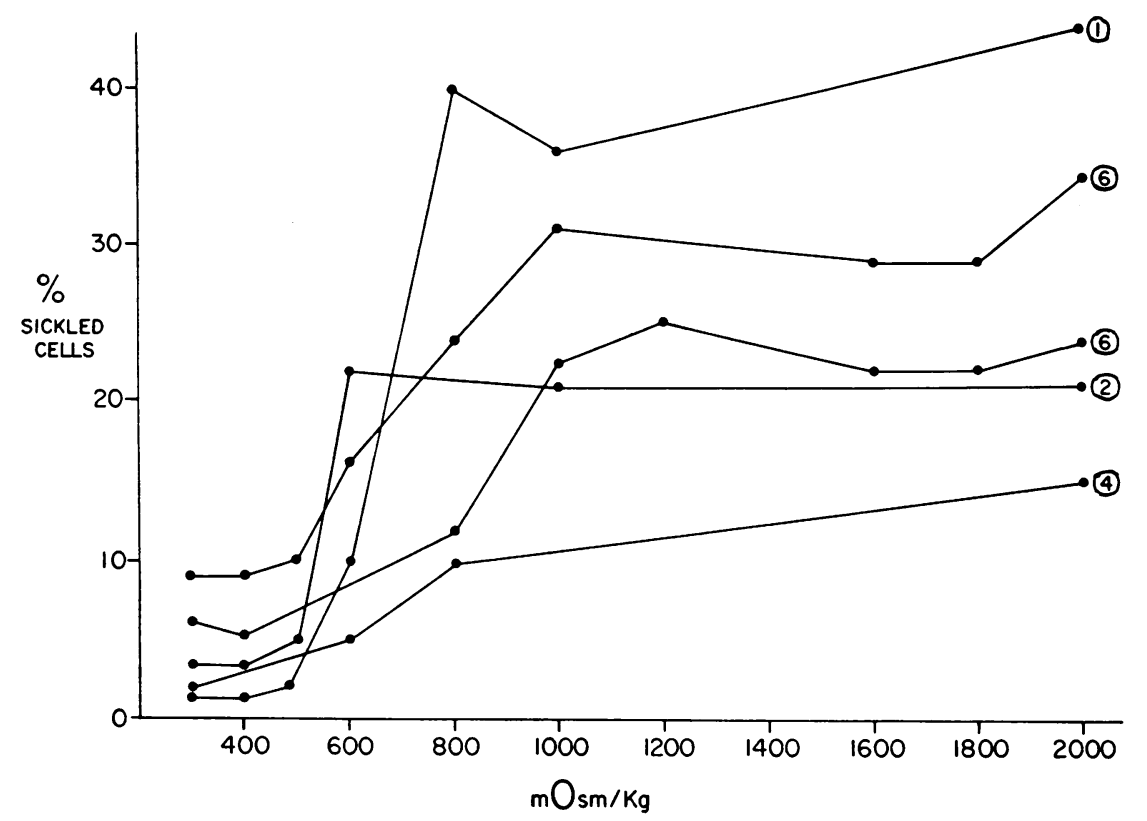

Fig. 2. EFFECT OF HYPERTONICITY UPON ERYTHROCYTE SICKLING IN PATIENTS WITH SICKLE-CELl ANEMIA (S-S DISEASE). Encircled numbers in this and succeeding figures refer to the patients of Table I.

flows was not improved when glucose instead of mannitol was infused into three patients in amounts that produced hyperglycemia and glucosuria ( $\mathrm{Ta}-$ ble III, Figure 7).
As reported by Keitel, Thompson, and Itano (9), breathing $100 \%$ oxygen for one hour did not improve $\mathrm{U}_{\max }$ in two patients with sickle-cell anemia (S-S).

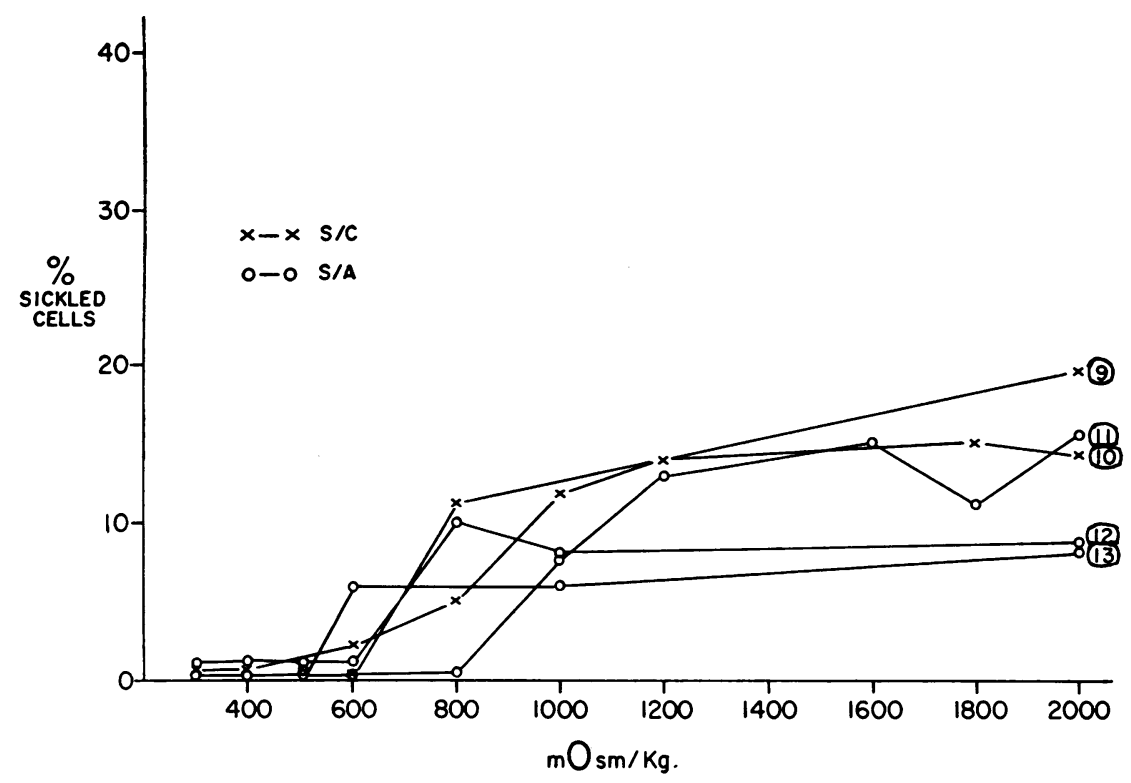

Fig. 3. EFFECT OF HYPERTONICITY UPON ERYTHROCYTE SICKLING IN PATIENTS WITH HEMOGLOBIN C (S/C) DISEASE AND SICKLE-CELL TRAIT (S/A). 


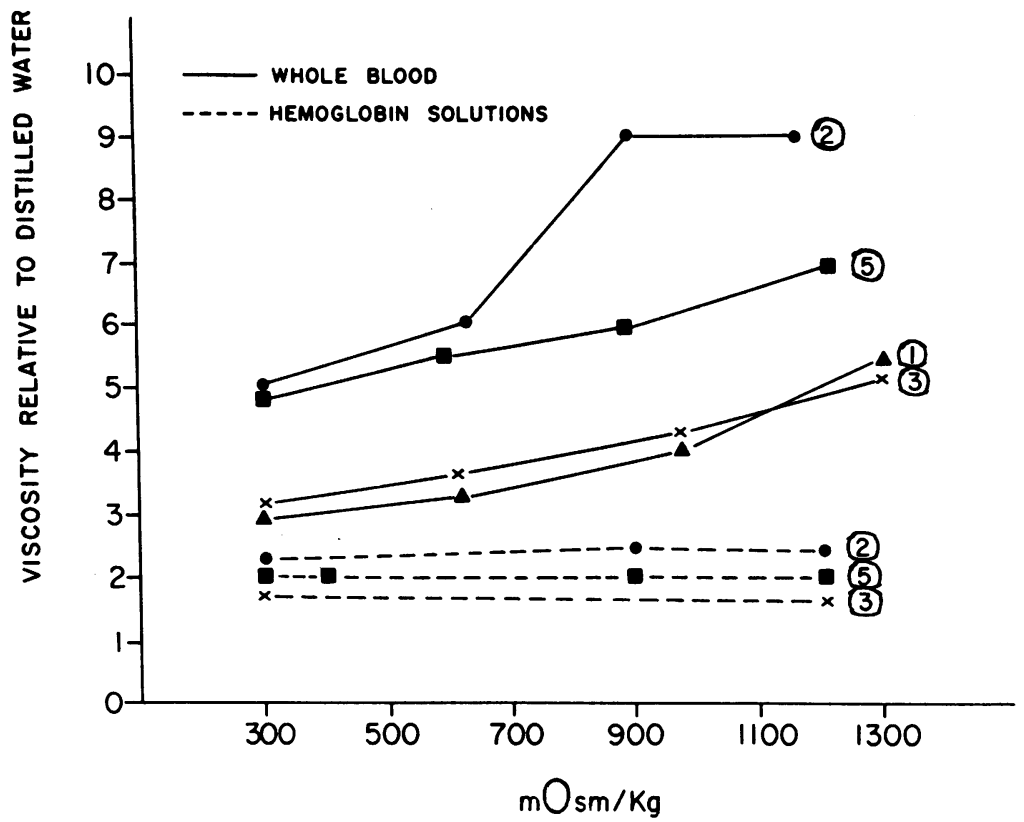

Fig. 4. EFFECT OF INCREASING SALT CONCENTRATION UPON THE VISCOSITY OF WHOLE BLOOD AND OF HEMOGLOBIN SOLUTIONS FROM PATIENTS WITH SICKLE-CELL ANEMIA.

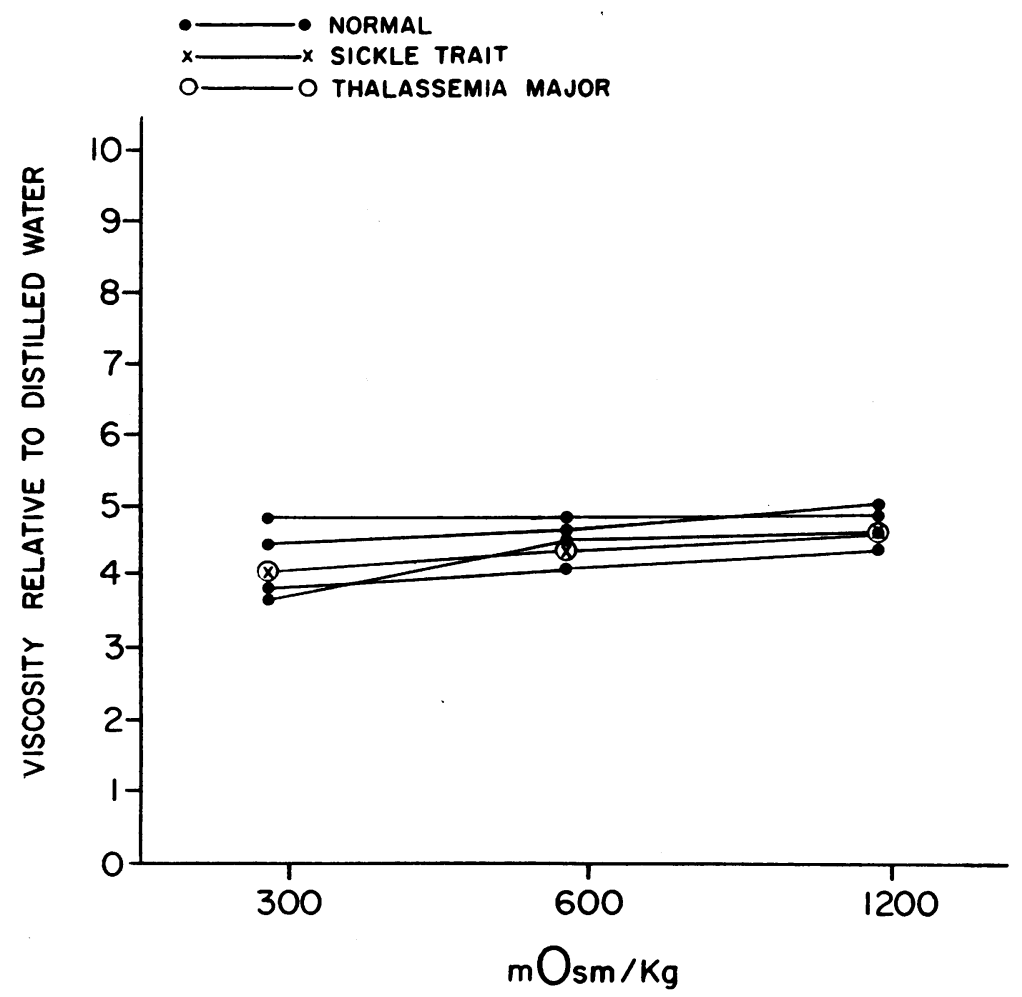

Fig. 5. EFFECT OF INCREASING SALT CONCENTRATION UPON THE VISCOSITY OF WHOLE BLOOD FROM PATIENTS WITHOUT SICKLE-CELL ANEMIA. 
TABLE II

Volume of packed cells in blood diluted with increasingly hypertonic solutions

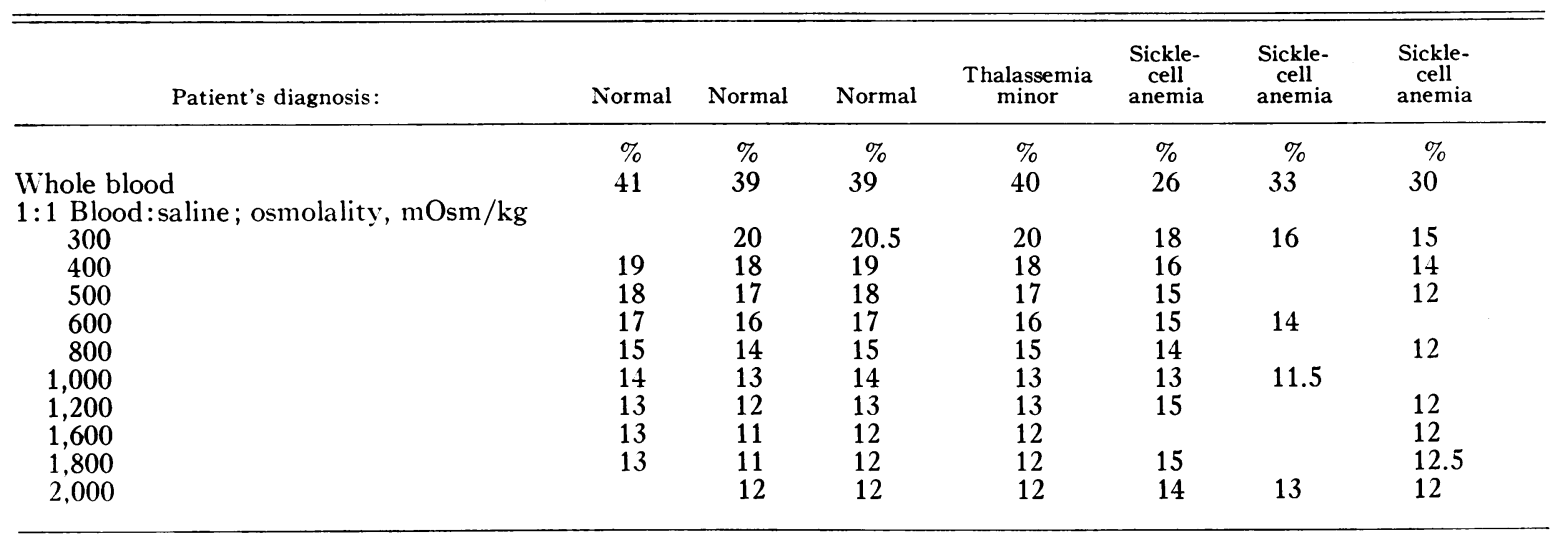

\section{DISCUSSION}

The effects of oxygen tension, $\mathrm{pH}$, temperature, and hemoglobin concentration upon the sickling phenomenon in human red blood cells containing S-hemoglobin $(\mathrm{S}-\mathrm{Hb})$ have been carefully studied (15). It has generally been concluded that reduced $\mathrm{S}-\mathrm{Hb}$ is necessary for the formation of sickle cells. Reduced S-Hb was shown by Perutz and Mitchison to have a much lower solubility than oxygenated $\mathrm{S}-\mathrm{Hb}$, which has a solubility approximating that of normal hemoglobin $(\mathrm{A}-\mathrm{Hb})$ at the ionic strength of the buffer employed (5.0 to 5.5) (16). During the process of deoxygenation, the configuration of the $\mathrm{S}-\mathrm{Hb}$ molecule is altered and a liquid, crystalline material or "tactoid" gel is formed $(16,17)$.

A suggestion that hypertonic buffered solutions might promote sickling is to be found in the data of Lange, Minnich, and Moore (18), and recently the same phenomenon has been observed by

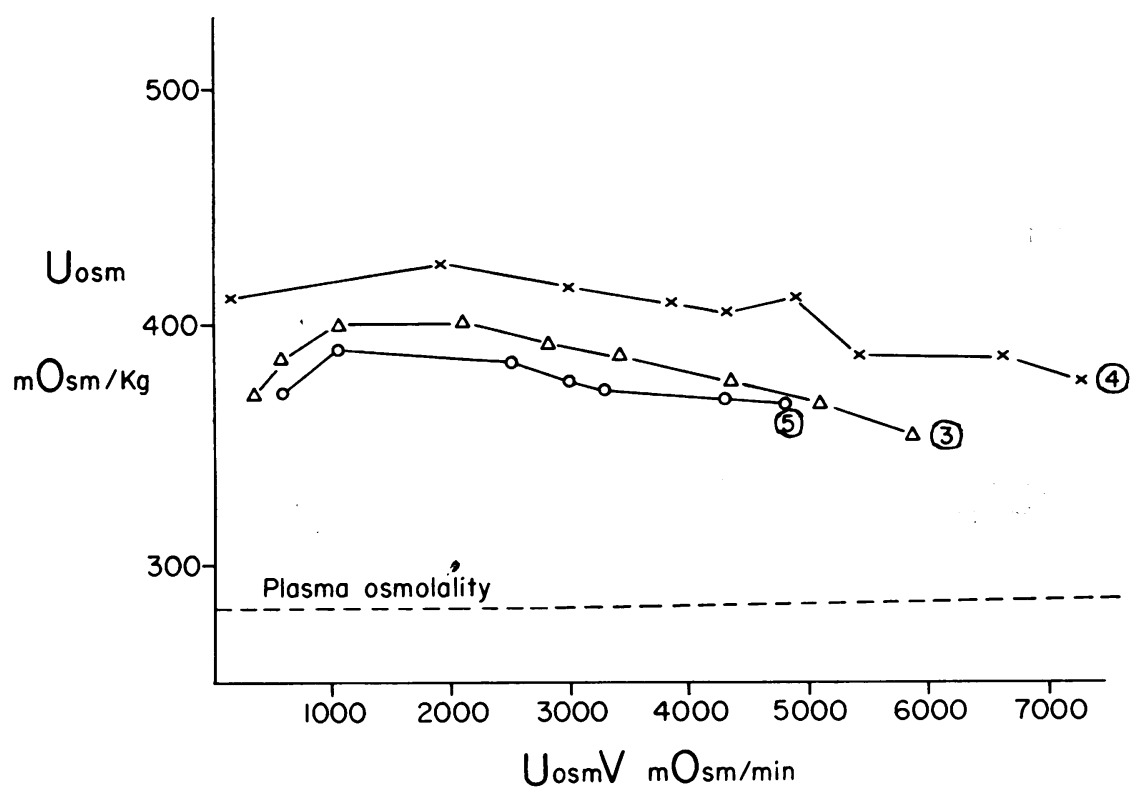

FIG. 6. EFFECT OF OSMOTIC DIURESIS UPON URINARY OSMOLALITY (U Osm ) IN THREE patients with SICKLE-CELl anemia. Solute excretion $\left(U_{o s m} V\right)$ is plotted along the abscissa. Urinary solute concentration remained relatively constant despite large increases in solute excretion induced by infusions of mannitol. 


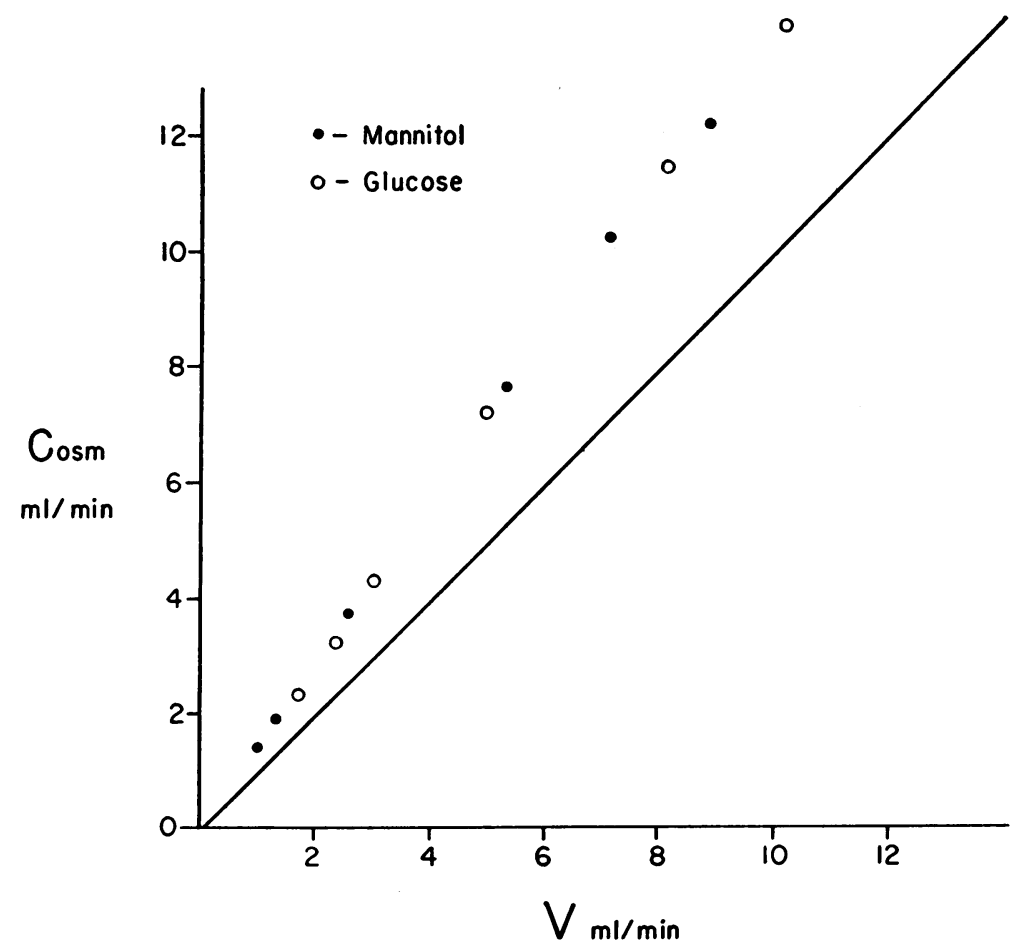

Fig. 7. Renal CONCENTRATING CAPACITY OF A PATIENT With SICKLE-CELL ANEMIA DURING OSMOTIC DIURESIS INDUCED WITH GLUCOSE AND WITH MANNIToL. Concentrating ability at both low and high flows was unaltered by substituting glucose for the nonmetabolized solute mannitol. Similar results were obtained in experiments on two other patients with sickle-cell anemia (S-S disease). Cosm, osmolar clearance.

Herbin, Ceriani, and Gotta (19). The present experiments show clearly that the sickling phenomenon may be elicited even in the presence of high oxygen tensions [at which almost all hemoglobin is presumably in the oxidized form $(7,8)$ ] simply by immersing cells containing $\mathrm{S}-\mathrm{Hb}$ in hypertonic salt solutions. This appears to be entirely a consequence of cellular dehydration, re-

TABLE III

Effect of infusions of mannitol and glucose on renal concentrating capacity in three patients with sickle-cell anemia*

\begin{tabular}{|c|c|c|c|c|c|}
\hline \multirow[b]{2}{*}{ Patient } & \multicolumn{2}{|c|}{$\begin{array}{c}\text { Mannitol } \\
\text { infusion }\end{array}$} & \multicolumn{2}{|c|}{$\begin{array}{l}\text { Glucose } \\
\text { infusion }\end{array}$} & \multirow{2}{*}{$\begin{array}{l}\text { Blood } \\
\text { sugar }\end{array}$} \\
\hline & $\mathrm{C}_{\text {IN }}$ & $\mathrm{T}_{\mathrm{m}}{ }^{\circ} \mathrm{H}_{2} \mathrm{O}$ & $C_{\text {IN }}$ & $\mathrm{T}_{\mathrm{m}^{\circ} \mathrm{H} 2 \mathrm{O}}$ & \\
\hline & $m l / m i n$ & $m l / m i n$ & $m l / m i n$ & $\mathrm{ml} / \mathrm{min}$ & $\mathrm{mg} / 100 \mathrm{ml}$ \\
\hline 3 & 124 & 4.00 & 136 & 4.50 & 483 \\
\hline 4 & 116 & 3.86 & 124 & 3.75 & 522 \\
\hline 5 & 120 & 3.40 & 112 & 3.32 & 516 \\
\hline
\end{tabular}

* During glucose infusions, urinary concentrations of glucose exceeded $2,000 \mathrm{mg}$ per $100 \mathrm{ml}$. Values for inulin clearance (CIN) and maximal reabsorption of solute-free water $\left(\mathrm{T}_{\mathrm{m}}^{\circ} \mathrm{H} \mathrm{H}_{\mathrm{O}}\right)$ are those observed during the single period associated with the largest reabsorption of solute-free
water $\left(\mathrm{T}^{\circ} \mathrm{H}, \mathrm{O}\right)$ obtained during each procedure. sulting in an increased concentration of hemoglobin within the red cell envelope, rather than a specific ionic effect of a high concentration of sodium salts upon the hemoglobin itself. The viscosity of oxygenated whole blood from patients with sickle-cell anemia is increased by the addition of salt because of the formation of sickled cells, but when oxygenated $\mathrm{S}-\mathrm{Hb}$ is liberated from its cellular boundaries, raising the concentration of sodium salts in the solution does not change the viscosity of the hemoglobin. Unlike the sickling promoted by low oxygen tensions, which takes two to four mihutes to become apparent at body temperature (20), sickling induced by hypertonic solutions occurs, and may be reversed, practically instantaneously. The effect can be simulated by hypertonic solutions of mannitol and sucrose, which do not enter cells and therefore exert osmotic effects across the red cell membrane, but not by urea, which enters red cells without dehydrating them (21). 
The concentration of sodium salts necessary to induce sickling is higher than that likely to be reached in peripheral blood even during the severest dehydration compatible with life. Indeed, the renal medulla is probably the only part of the body in which extracellular tonicity ever achieves the level necessary in vitro to promote sickling. The concentration of salt at which maximal sickling was observed corresponds approximately to that which Olmstead calculated would promote the maximal efflux of water from rabbit red cells (22), and to the concentration inducing maximal shrinkage of human red blood cells in the few experiments depicted in Table II. Roughly $40 \mathrm{ml}$ of water can be withdrawn from $100 \mathrm{ml}$ of red cells by immersing them in hypertonic saline (22). At the resulting hemoglobin concentration of about $57 \mathrm{~g}$ per $100 \mathrm{ml}$ of red cells (or $81.5 \mathrm{~g}$ per $100 \mathrm{ml}$ of $\mathrm{H}_{2} \mathrm{O}$ ), oxygenated $\mathrm{A}-\mathrm{Hb}$ remains fluid, but oxygenated $\mathrm{S}-\mathrm{Hb}$ apparently assumes the form of a gel.

Perutz, Liquori, and Eirich reported that oxygenated $\mathrm{S}-\mathrm{Hb}$ could be crystallized from solution in an orthorhombic form containing eight molecules per cell, with longer and thinner dimensions than those of crystals of $\mathrm{A}-\mathrm{Hb}$, which contains half as many molecules per cell (23). When erythrocytes containing oxygenated $\mathrm{S}-\mathrm{Hb}$ are dehydrated by immersion in hypertonic saline, regular molecular aggregates unique to $\mathrm{S}-\mathrm{Hb}$ probably form, thereby deforming the shape of the red cell in characteristic fashion.

The peculiar inability of patients with sicklecell anemia to concentrate their urine normally has suggested to several workers (11-14) that hyposthenuria might be related in some way to sickling of the erythrocytes in capillaries of the renal medulla, perhaps initiated by the relatively low oxygen tension of this portion of the kidney. occasioned by the countercurrent flow of blood through medullary capillary loops (24). Two facts are relevant to this hypothesis. First, the oxygen tension of maximally concentrated human urine (reflecting, it is thought, the oxygen tension of medullary tissue), though lower than that of renal venous blood. is not lower than 35 to $40 \mathrm{~mm}$ $\mathrm{Hg}(25,26)$. This is the level at which cells from sicklemic patients just begin to show an appreci- able increase in sickle formation $(18,20) .^{2}$ Second, the circulation time through the renal medulla (of the dog) is approximately 30 seconds (28). In vitro at $37^{\circ} \mathrm{C}$ it takes two to four minutes of exposure to low oxygen tensions before sickling begins (20). There is some reason to believe, then, that low oxygen tension alone might not habitually account for a substantial increase in sickling of erythrocytes as they pass through the renal medullary capillaries.

We wish to propose that in patients with sicklecell anemia, sickling may take place in the capillaries of the medulla, but that this is partly related to another property of this tissue, namely, its hypertonicity. Normal red blood cells passing through the medulla of a kidney excreting a highly concentrated urine are crenated (29), resuming their normal shape when they emerge into the isotonic environment of the cortex. Sickle anemia cells entering a hypertonic renal medulla would immediately become sickled. This might influence renal concentrating ability in the following way. 1) Sickling would increase the viscosity of blood entering the medulla and therefore the resistance to blood flow through the medullary capillaries. 2) Blood flow through the renal medulla and papilla would thereby be selectively decreased, without important changes in cortical blood flow and glomerular filtration rate. The latter parameters are normal or elevated in children and young adults with sickle-cell anemia $(30,31)$. 3) The supply of oxygen and metabolic substrates to renal tubular cells lining the loops of Henle would be diminished. 4) As a result, active reabsorption of sodium by these cells would be reduced (or permeability to water of the ascending limb of Henle's loop might be increased, or back-diffusion of sodium into the ascending limb might be enhanced). 5) Hypertonicity of the medullary interstitium would therefore be decreased, resulting in a lower concentration of solutes in the final urine. 6) As medullary tonicity was lowered, sickling in medullary capillaries would be less pronounced, permitting medullary blood flow to increase. The final levels of blood flow to the

2 The formation of sickled cells would be enhanced by an acid $\mathrm{pH}$ (18). Although it is known that lactic acid is added to the blood perfusing the renal medulla (27), measurements of the $\mathrm{pH}$ of blood from medullary capillaries in experimental animals are not yet available. 
medulla, active sodium reabsorption, medullary sodium concentration, and maximal urinary solute concentration, would, in this formulation, depend upon the equilibrium point of a feedback system in which medullary tonicity and medullary blood flow influence each other.

By decreasing intermolecular distances within the red cell, intracellular dehydration induced by hypertonicity might be expected to enhance the additional tendency to sickling produced by hypoxia or acidity. The dissociation curve of normal human hemoglobin is shifted slightly toward the reduced form by high concentrations of sodium and potassium chloride (32). If this were true of $\mathrm{S}-\mathrm{Hb}$, it would suggest still another way in which hypertonicity and hypoxia might prove synergistic in promoting sickle formation. Interactions of this kind might help to explain hyposthenuria in patients with sickle-cell trait (Patients 14 and 16, Table I) whose cells did not sickle in oxygenated hypertonic saline, and also explain the fact that the maximal urinary osmolalities of many patients with sickle-anemia (see Patients 1 to 4 , Table I) are lower than the concentrations of saltinducing sickling in vitro in the present experiments.

Indirect evidence supporting this general hypothesis may be summarized as follows. 1) Multiple transfusions of normal red cells reverse the renal concentrating defect in children with sicklecell anemia (9). (This is less often true in adults, in whom irreversible structural damage to the medulla has had time to develop.) 2) The defect in concentrating ability of sicklemic patients is most pronounced at low urine flow. During osmotic diuresis, when medullary blood flow increases (33) and the tonicity of the medullary interstitial fluid is presumably diminished (34), the ability of the kidneys to reabsorb solute-free water improves and approaches normal (11-14) (Figures 6 and 7). This discrepancy is in sharp contrast to other states characterized by impaired renal concentrating capacity, such as potassium deficiency or hypercalcemia, where maximal urinary concentration and $\mathrm{T}_{\mathrm{H}_{2} \mathrm{O}}^{\mathrm{O}}$ are simultaneously reduced (35-38). Indeed, in the latter situations, urine, though initially hypertonic, often becomes more dilute than plasma in the course of an osmotic diuresis. 3) Kidneys of sicklemic patients frequently show severe capillary stasis, ischemic necrosis, peritubular hemorrhage, and interstitial scarring in the medullary pyramids $(39,40)$.

The hypothesis that net reabsorption of sodium by medullary tubules may be diminished by selectively decreasing blood flow through medullary capillaries has not yet been tested experimentally. Oxygen uptake is linked with sodium transport in many tissues, and oxygen utilization is proportional to sodium transport in mammalian kidneys under certain circumstances (41-43). Although the medulla of the kidney has an active anaerobic metabolism (44), lactic acid accounts for only a portion of the glucose utilized by medullary tissue of the hamster in vivo (27), and it seems possible that oxidative metabolism mav normally contribute a substantial fraction of the total energy requirement of the medulla. Restriction of blood flow to the renal medulla might decrease the energy available for active transport of sodium by decreasing the availability to renal tubular cells of oxygen or of substrate. (Alternatively, a decrease in the supply of energy available to the cells lining the ascending limb of Henle's loop might alter their permeability to water, or enhance the backdiffusion of sodium into the tubular lumen, so that the net reabsorbate transferred into medullary interstitial fluid would be less concentrated in sodium. In either case, medullary tonicity, and hence final urinary solute concentration, would fall. ${ }^{3}$ ) The present experiments suggest that the supply of glucose to the renal medulla does not limit concentrating ability in sicklemic patients, since urinary concentration did not improve when hyperglycemia and glycosuria were produced with glucose infusions.

Renal complications of sickle-cell disease include gross and microscopic hematuria, proteinuria, pyelonephritis, and occasionally renal insufficiency (1). Whereas both cortex and medulla are scarred and congested in cases with advanced renal damage (40), the ischemic alterations in kidneys removed for unilateral bleeding are most prominent in the medulla (39). In all likelihood

\footnotetext{
${ }^{3}$ Slowing of capillary flow through the renal medulla per se, if unaccompanied by a decrease in sodium reabsorption or a change in tubular permeability to water, would result in an increase in medullary tonicity, since the hypertonic concentrations of sodium reabsorbed from loops of Henle and deposited in the medullary interstitium would be removed less rapidly (24).
} 
these result from intravascular sickling of erythrocytes in medullary capillaries. Since sickling is promoted by hypertonicity, and since the salt concentration of the medullary blood vessels is reduced close to isotonic levels by water diuresis (45), it would seem reasonable to suggest that patients with sickle-cell anemia might avoid secondary renal damage if they habitually drank enough water to keep their urine dilute.

The high salt concentration of the renal medulla has another and broader hematological implication. Though only about $1 \%$ of the blood flow to the kidneys passes through the medulla (24), with a red blood cell count about half that of peripheral blood (29), nevertheless, in the course of a day, more erythrocytes than the entire red cell population of the body may become crenated at least once as they circulate through this small, hypertonic region. Perhaps this, in addition to other mechanical and biochemical traumata, contributes to the wear and tear that eventually limit the life of the red cell.

\section{ST MIMARY}

1) Erythrocytes containing S-hemoglobin become sickled when they are immersed in hyperosmotic solutions, even at the oxygen tension of room air and at normal body temperature and $\mathrm{pH}$. The phenomenon is probably a result of cellular dehydration.

2) It is suggested that when such cells enter the hypertonic and hypoxic milieu of the renal medulla, sickling is promoted, thereby increasing blood viscosity, selectively restricting blood flow to the medulla, limiting the production of a high concentration of sodium in the medullary interstitial fluid, and producing the hyposthenuria that characterizes patients with sickle-cell anemia.

\section{REFERENCES}

1. Schlitt, L. E., and H. G. Keitel. Renal manifestations of sickle cell disease: a review. Amer. J. med. Sci. 1960, 239, 773.

2. Wirz, H. Der osmotische Druck des Blutes in der Nierenpapille. Helv. physiol. pharmacol. Acta 1953, 11, 20.

3. Gottschalk, C. W., and M. Mylle. Micropuncture study of the mammalian urinary concentrating mechanism: evidence for the countercurrent hypothesis. Amer. J. Physiol. 1959, 196, 927.

4. Daland, G. A., and W. B. Castle. A simple and rapid method for demonstrating sickling of the red blood cells: the use of reducing agents. J. Lab. clin. Med. 1948, 33, 1082.

5. Wintrobe, M. M. Clinical Hematology. Philadelphia, Lea \& Febiger, 1961, p. 379.

6. Walser, M., D. G. Davidson, and J. Orloff. The renal clearance of alkali-stable inulin. J. clin. Invest. $1955,34,1520$.

7. Fowler, N. O., O. Smith, and J. C. Greenfield. Arterial blood oxygenation in sickle cell anemia. Amer. J. med. Sci. 1957, 234, 449.

8. Fraimow, W., T. Rodman, H. P. Close, R. Cathcart, and M. K. Purcell. The oxyhemoglobin dissociation curve in sickle cell anemia. Amer. J. med. Sci. 1958, 236, 225.

9. Keitel, H. G., D. Thompson, and H. A. Itano. Hyposthenuria in sickle cell anemia: a reversible renal defect. J. clin. Invest. 1956, 35, 998.

10. Kunz, H. W., E. L. Pratt, G. W. Mellin, and M. W. Cheung. Impairment of urinary concentration in sickle cell anemia. Pediatrics 1954, 13, 352.

11. Zarafonetis, C. J. D., J. D. McMaster, L. Molthan, and W. A. Steiger. Apparent renal defect in sicklemic individuals. Amer. J. med. Sci. 1956, 232, 76.

12. Levitt, M. F., A. D. Hauser, M. S. Levy, and D. Polimeros. The renal concentrating defect in sickle cell disease. Amer. J. Med. 1960, 29, 611.

13. Heinemann, H. O., and M. W. Cheung. Renal concentrating mechanism in sickle-cell anemia. J. Lab. clin. Med. 1957, 49, 923.

14. Whitten, C. F., and A. A. Younes. A comparative study of renal concentrating ability in children with sickle cell anemia and in normal children. J. Lab. clin. Med. 1960, 55, 400.

15. Harris, J. W. The role of physical and chemical factors in the sickling phenomenon. Progr. Hemat. 1959, 2, 47.

16. Perutz, M. F., and J. M. Mitchison. State of haemoglobin in sickle-cell anaemia. Nature (Lond.) 1950, 166, 677.

17. Harris, J. W. Studies on the destruction of red blood cells. VIII. Molecular orientation in sickle cell hemoglobin solutions. Proc. Soc. exp. Biol. (N. Y.) 1950, 75, 197.

18. Lange, R. D., V. Minnich, and C. V. Moore. Effect of oxygen tension and of $\mathrm{pH}$ on the sickling and mechanical fragility of erythrocytes from patients with sickle cell anemia and the sickle cell trait. J. Lab. clin. Med. 1951, 37, 789.

19. Herbin, L. F., R. Ceriani, and H. Gotta. Sicklemia. Estudio sobre la funcion renal $\mathrm{y}$ eritrocinesis. Pren. méd. argent. 1961, 48, 1526.

20. Allison, A. C. Observations on the sickling phenomenon and on the distribution of different haemoglobin types in erythrocyte populations. Clin. Sci. 1956, 15, 497.

21. $\mathrm{Wu}, \mathrm{H}$. Separate analyses of the corpuscles and the plasma. J. biol. Chem. 1922, 51, 21.

22. Olmstead, E. G. Efflux of red cell water into buf- 
fered hypertonic solutions. J. gen. Physiol. 1960, 43, 707.

23. Perutz, M. F., A. M. Liquori, and F. Eirich. X-ray and solubility studies of the haemoglobin of sicklecell anaemia patients. Nature (Lond.) 1951, 167, 929.

24. Ullrich, K. J., K. Kramer, and J. W. Boylan. Present knowledge of the counter-current system in the mammalian kidney. Progr. cardiovasc. Dis. 1961, 3, 395.

25. Hong, S. K., J. W. Boylan, A. M. Tannenberg, and H. Rahn. Total and partial gas tensions of human bladder urine. J. appl. Physiol. 1960, 15, 115.

26. Rennie, D. W., R. B. Reeves, and J. R. Pappenheimer. Oxygen pressure in urine and its relation to intrarenal blood flow. Amer. J. Physiol. 1958, 195, 120.

27. Ruiz-Guinazu, A., G. Pehling, G. Rumrich, and K. J. Ullrich. Glucose und Milchsaurekonzentration an der Spitze des vascularen Gegenstromsystems im Nierenmark. Pflügers Arch. ges. Physiol. 1961, 274, 311.

28. Kramer, K., K. Thurau, and P. Deetjen. Hämodynamik des Nierenmarkes (I). Pflügers Arch. ges. Physiol. 1960, 270, 251.

29. Ullrich, K. J., G. Pehling, and H. Stockle. Hämoglobin-konzentration, Erythrocytenzahl und Hämatokrit im vasa recta Blut. Pflügers Arch. ges. Physiol. 1961, 273, 573.

30. Etteldorf, J. N., A. H. Tuttle, and G. W. Clayton. Renal function studies in pediatrics: I. Renal hemodynamics in children with sickle cell anemia. Amer. J. Dis. Child. 1952, 83, 185.

31. Etteldorf, J. N., J. D. Smith, A. H. Tuttle, and L. W. Diggs. Renal hemodynamic studies in adults with sickle cell anemia. Amer. J. Med. 1955, 18, 243.

32. Rossi-Fanelli, A., E. Antonini, and A. Caputo. Studies on the relations between molecular and functional properties of hemoglobin. II. The effect of salts on the oxygen equilibrium of human hemoglobin. J. biol. Chem. 1961, 236, 397.

33. Thurau, K., P. Deetjen, and K. Kramer. Hämodynamik des Nierenmarkes. II. Wechselbeziehung zwischen vascularem und tubularem Gegenstrom- system bei arteriellen Drucksteigerungen, Wasserdiurese und osmotischer Diurese. Pflügers Arch. ges. Physiol. 1960, 270, 270.

34. Malvin, R. L., and W. S. Wilde. Washout of renal countercurrent $\mathrm{Na}$ gradient by osmotic diuresis. Amer. J. Physiol. 1959, 197, 177.

35. Rubini, M. E. Water excretion in potassium-deficient man. J. clin. Invest. 1961, 40, 2215.

36. Giebisch, G., and R. Lozano. The effects of adrenal steroids and potassium depletion on the elaboration of an osmotically concentrated urine. J. clin. Invest. 1959, 38, 843.

37. Epstein, F. H., D. Beck, F. A. Carone, H. Levitin, and A. Manitius. Changes in renal concentrating ability produced by parathyroid extract. J. clin. Invest. 1959, 38, 1214.

38. Zeffren, J. L., and H. O. Heineman. Reversible defect in renal concentrating mechanism in patients with hypercalcemia. Amer. J. Med. 1962, 33, 54.

39. Mostofi, F. K., C. F. VanderBruegge, and L. W. Diggs. Lesions in kidneys removed for unilateral hematuria in sickle-cell disease. Arch. Path. 1957, 63, 336.

40. Bernstein, J., and C. F. Whitten. A histologic appraisal of the kidney in sickle cell anemia. Arch. Path. 1960, 70, 407.

41. Deetjen, P., and K. Kramer. Der $\mathrm{O}_{2}-$ Verbrauch der Warmblutniere unter veranderten Bedingungen der Na-Ruckresorption. Pflügers Arch. ges. Physiol. 1961, 274, 60.

42. Thaysen, J. H., N. A. Lassen, and O. Munck. Sodium transport and oxygen consumption in the mammalian kidney. Nature (Lond.) 1961, 190, 919.

43. Lassen, U. V., and J. H. Thaysen. Correlation between sodium transport and oxygen consumption in isolated renal tissue. Biochim. biophys. Acta (Amst.) 1961, 47, 616.

44. Dickens, F., and H. Weil-Malherbe. Metabolism of normal and tumour tissue. XIV. A note on the metabolism of medulla of kidney. Biochem. J. 1936, 30, 659.

45. Gottschalk, C. W. Micropuncture studies of tubular function in the mammalian kidney. Physiologist 1961, 4, 35 . 